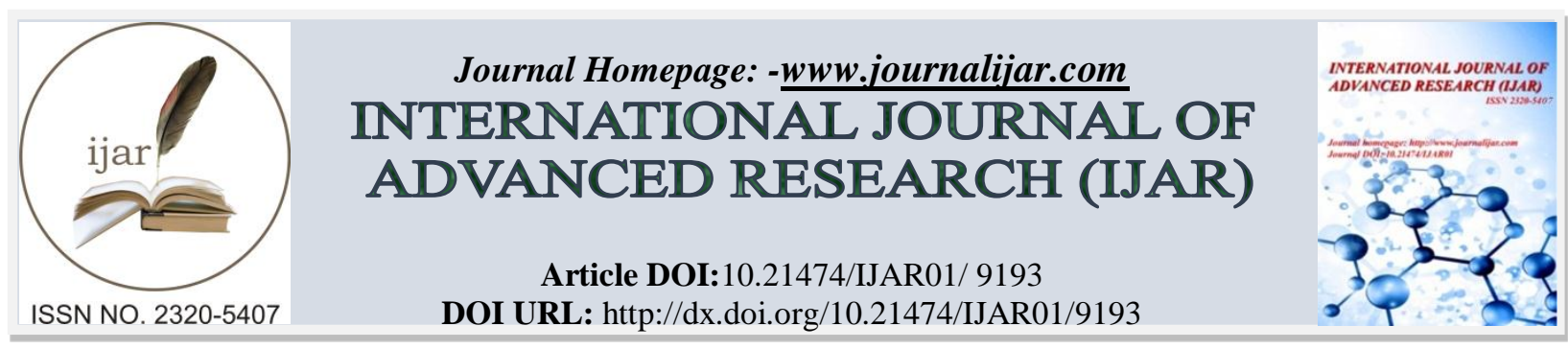

RESEARCH ARTICLE

\title{
A STUDY EVALUATING THE POSITION OF THE OCCLUSAL PLANE RELATIVE TO PAROTID PAPILLA IN KASHMIRI POPULATION.
}

1. Senior resident, Department of Prosthodontics, GDC\&H.

2. Associate professor, Department of Prosthodontics, GDC\&H.

\section{Manuscript Info}

Manuscript History

Received: 02 April 2019

Final Accepted: 04 May 2019

Published: June 2019

Key words:-

Occlusal plane, Linea alba bucallis,

UNC-15 periodontal probe.

\section{Abstract}

Introduction: It is challenging for prosthodontist to reorient and relocate the lost occlusal plane in edentate patients. Several intraoral landmarks that help in re-orienting and relocating the lost occlusal plane.

Aims and objectives: This study was conducted to evaluate the position of occlusal plane relative to parotid papilla in dentate subjects.

Materials and methods: A total of 100 patients with 50 males and 50 females were examined to measure the distance of mesiobuccal cusp tip maxillary $2^{\text {nd }}$ molar to inferior border of parotid papilla with UNC-15 periodontal probe in maximum intercuspal position.

Results: The mean distance of all parotid papillae above the plane of occlusion was $3.7 \mathrm{~mm}$, while for the right papilla, it was $3.2 \mathrm{~mm}$, and for the left papilla it was $3.6 \mathrm{~mm}$. F-test [ANOVA] showed the difference in measurements between right and left papillae to be significant at the $\mathrm{p}$-value of 0.05 and $\mathrm{p}$-value of 0.01 levels.

Summary and conclusion: The parotid papilla can be used for the assessing and confirming the position of the occlusal plane while rehabilitating a completely edentate patient.

Copy Right, IJAR, 2019,. All rights reserved.

\section{Introduction:-}

The occlusal plane may be well defined as the average planar curvature of incisal and occlusal surfaces of the anterior and posterior teeth respectively. With loss of complete dentition, there is loss of the plane of occlusion. It is very challenging for the restoring dentist to relocate and re-orient the occlusal plane in edentate patient. Several intraoral landmarks that help in re-orienting and relocating the lost occlusal plane are retromolar pad, lateral border of tongue, buccinator groove, linea alba buccalis, rima oris and parotid papilla. In the natural dentition, the plane of occlusion is first established by the mandibular teeth, to which the maxillary teeth then adapt themselves. Sicher and DuBrul' stated that the level of the parotid 
papilla is known to be at a position that, although variable, is adjacent to the maxillary second molar. According to Yamane et al the papilla lies above the occlusal plane, and Lundquist and Luther found it to be located superior to the buccal cusp tips of the maxillary molars.

Aims and objectives:

this study was conducted to evaluate the position of the occlusal plane relative to parotid papilla in dentate subjects.

Materials and methods:-

The subjects were selected from the patients reporting the department of prosthodontics, GDC \& $\mathrm{H}$ Srinagar.

\section{Sample size:}

A total of 100 patients with 50 males and 50 females were examined

\section{Including criteria:}

1. Age: $18-60$

2. Completely dentate

3. Non restored molars with intact buccal cusps

\section{Excluding criteria:}

1. Age: subjects aged less than 18years

2. Partially edentate

3. Completely edentate

4. Generalized attrition

5. Restored molars with worn out cusps

\section{Methodology:-}

The subjects were examined to determine the position of the inferior border of parotid papilla to the mesio-buccal cusp tip of maxillary second molar on right and left sides. The utmost care was taken to ensure that teeth were in maximum intercuspal position and parotid papilla in undistorted form. The instrument that was used to measure the distance was UNC-15 PROBE \{HuFriedy, Chicago . This probe is $15 \mathrm{~mm}$ long with marking at each millimeter and color coding at every $5^{\text {th }}, 10^{\text {th }}$ and $15^{\text {th }} \mathrm{mm}$.

\section{Results:-}

The mean distance of all parotid papillae above the plane of occlusion was $3.7 \mathrm{~mm}$, while for the right papilla, it was $3.2 \mathrm{~mm}$, and for the left papilla it was $3.6 \mathrm{~mm}$. F-test [ANOVA] showed the difference in measurements between right and left papillae to be significant at the p-value of 0.05 and p-value of 0.01 levels. The same mean distances were significant for men at both levels, while women yielded means of $3.2 \mathrm{~mm}$ for the right side and $3.4 \mathrm{~mm}$ for the left side [not statistically significant].

\section{Discussion:-}

This study is clinically very significant as it describes the position of parotid papilla relative to the occlusal plane in dentate subjects. The parotid papilla acts as the reference anatomic land mark in reorienting and relocating the lost occlusal plane in edentate patients. The papillae were located slightly more than $3 \mathrm{~mm}$ above the occlusal plane. This distance of $3.3 \mathrm{~mm}$ can be used as a guideline to establish the occlusal plane the complete dentures.

Lundquist and Luther suggested that the parotid papilla was located $4 \mathrm{~mm}$ above the occlusal plane, which correlates with the results of this study. 


\section{Summary and conclusion:-}

This study determined that a fairly constant relationship exists between the parotid papilla and the occlusal plane.

The parotid papilla can be used for the assessing and confirming the position of the occlusal plane while rehabilitating a completely edentate patient.

\section{References:-}

1. Swenson MG, Complete Denture, 2nd ed. St. Louis: Mosby Company, 1990, 177-80

2. Glossary of Prosthodontic Terms. 8th ed. St. Louis: CV Mosby, 2005.

3. Zarb GA, Bolender CL, Carlsson GE. Boucher's Prosthodontic Treatment for Edentulous Patients. 11th ed. St. Louis: Mosby Company, 2003; 3-46:183-96.

4. Russell Augsburger H. occlusal plane relation to facial type. Journal of prosthetic dentistry. 1953; 3(6):755-770.

5. Yahia Ismail H. Position of the occlusal plane in natural and artificial teeth. Journal of prosthetic dentistry. 1968; 20(5):407-11.

6. Williams DR. Occlusal plane orientation in complete denture construction. J Dent. 1982; 10:311-6.

7. Foley PF. A study of the position of the parotid papilla relative to the occlusal plane. Journal of prosthetic dentistry. 1978; 53(1):124-26.

8. Lundquist D and Luther: The occlusal plane determination. J PROSTHET DENT; 23:489, 1970. 